\title{
Psychological symptoms in the elderly living alone during the pandemic COVID-19
}

\author{
Priscilla Machado Montezano Bastos ${ }^{1 *}$; Amanda Ribeiro de Almeida Espíndola ${ }^{1}$; Fernando Bezerra \\ Silva $^{1}$; Laína Adelaide Xavier da $\operatorname{Costa}^{1}$; Sinomara dos Santos Mendes do Nascimento' ${ }^{1}$;haiz Kétura \\ Cajueiro Estivalle Bilhalva ${ }^{1_{1}}$
}

\begin{abstract}
1 Department of Psychology, Center for Humanities, University Center of Vitória de Santo Antão (UNIVISA), Vitória de Santo Antão, Brazil E-mail address: pmontezano73@hotmail.com (Priscilla Machado Montezano Bastos), amandaa-almeida@hotmail.com (Amanda Ribeiro de Almeida Espíndola), fernandosmit@hotmail.com (Fernando Bezerra Silva), lainax22@gmail.com (Laína Adelaide Xavier da Costa), sinomara@hotmail.com (Sinomara dos Santos Mendes do Nascimento), thaiz_ketura@hotmail.com (Thaiz Kétura Cajueiro Estivalle Bilhalva). ${ }^{*}$ Corresponding author
\end{abstract}

\section{To cite this article:}

Montezano Bastos, P. M.; Espíndola, A. R. A; Silva, F. B.; Da Costa, L. A. X.; Nascimento, S. S. M.; Bilhalva, T. K. C. E. Psychological symptoms in the elderly living alone during the pandemic COVID-19. International Journal of Sciences. Vol. 1, No. 1, 2021, pp. 1-4.

Received: 01 24, 2021; Accepted: 01 30, 2021; Published: 02 02, 2021

\begin{abstract}
There is a worldwide trend in the increase of the elderly population and with this health care increases and with the new COVID-19 virus, this population in particular needs redoubled care. This research, conducted through the Google Forms platform, relates to the theme "Psychological symptoms during the pandemic in isolated elderly". Through a statistical analysis using the SPSS software, we noticed that most of the answers reinforce the idea that greater care and investment is needed with the mental health of the elderly, especially at this time of pandemic and social isolation. The information gathered indicated the need for greater psychological support, either face-to-face or virtual for this group specifically.
\end{abstract}

Keywords: Pandemic. Old. Mental health. SPSS. COVID-19.

\section{Introduction}

There is a worldwide trend towards the increase of the elderly population, it is interesting that research and studies on this population also follow such growth and that there is concern about the improvement of quality of life and health both physical and psychological. Brazil has more than 28 million people over the age of 60 , a figure that represents $13 \%$ of the country's population. And this percentage tends to double in the coming decades, according to the Population Projection, published in 2018 by the Brazilian Institute of Geography and Statistics ( IBGE , 2018), such information was of indispensable importance for the choice of this portion of the population as the target audience of the research described in this work that aims to gather information and answers about psychological symptoms in the group of over sixty years due to social isolation.

The status of the elderly in article 15 says that "Comprehensive care is ensured for the health of the elderly, through the Unified Health System (SUS), guaranteeing universal and equal access, together articulated and continuous of actions and services, for the prevention, promotion, protection and recovery of health, including special attention to diseases that preferentially affect the elderly." (BRASIL, 2003), in view of this safety, the application of efficient measures at levels of protection and recovery of psychological diseases in the elderly is increasingly necessary and urgent.

"The clinical picture of COVID-19 is similar to that of other respiratory viruses, namely fever, usually dry cough, tiredness and, in more severe cases (5\%), dyspnea, pulmonary bleeding, severe lymphopenia, and renal failure. In $80 \%$ of cases, symptoms are mild. Its main characteristic is high transmissibility, generating an acute respiratory syndrome, ranging from mild to very severe cases with respiratory failure, whose lethality rate varies mainly according to age group and associated clinical conditions" (GRINCENKOV, 2020). This syndrome currently brings important changes in the habits of society, with this also influences the physical and mental health of the entire population, the concern with the global health crisis sets precedents for mental illnesses arising from social isolation and together, issues such as fear of contracting the disease, individual and collective financial insecurity and other aspects of life in society in this pandemic context (MINISTRY OF HEALTH OF BRAZIL , 2020). The research was centered on identifying possible psychological symptoms acquired or intensified by this given population 
during this period.

The choice for this target audience was especially due to the high vulnerability that this group presents due to the common presence of comorbidities that bring increased risk of aggravation and also mortality to the elderly and because of these issues are especially of the elderly and their relatives who resort to social distancing as a method of prophylaxis in coping with the virus (SILVA; VIANA; LIMA, 2020).

Caring for the elderly is the responsibility of all who make up society, contributing to the strengthening of the elderly so that they can fully exercise their abilities and enjoy health at this stage of life is a way of caring with respect to the individual history to which they have built and also mirror a future of social well-being (SANTOS; BRANDISHED; ARAÚJO, 2020)..

\section{Methodology}

This was a survey conducted in October 2020, through the Google Forms platform, with 20 questions that were sent to 74 contacts distributed by the team components aimed at a specific target audience (relatives of the elderly isolated in times of pandemic). After receiving the research, the data were released in the SPSS program (made available by UNIVISA institution), the answers were statistically analyzed and their results presented here with the most compelling questions related to the research.

\section{Results and Discussion}

\subsection{Frequency Tables}

According to the frequency analysis, it was possible to observe that when asking about the fact that elderly relatives are complying with the rules of social isolation, $78.4 \%$ answered yes (Table 1).

\begin{tabular}{ccccc}
\hline Table 1. Frequency of elderly people who comply with the rules of social isolation. \\
\hline Frequency & Percentage & Valid & Cumulative \\
percentage & percentage \\
Yes & 58 & 78,4 & 78,4 & 78,4 \\
No & 16 & 21,6 & 21,6 & 100,0 \\
Total & 74 & 100,0 & 100,0 & \\
\hline
\end{tabular}

It was noticed that of the 74 people interviewed, 48 of them reported that the fear of contamination did not decrease the quality of their elderly relative, perhaps it is because of this fear that isolation is respected according to Table 2 and Figure 1 .

\begin{tabular}{|c|c|c|c|}
\hline relative? & & & \\
\hline Frequency & Percentage & $\begin{array}{c}\text { Valid } \\
\text { percentage }\end{array}$ & $\begin{array}{l}\text { Cumulative } \\
\text { percentage }\end{array}$ \\
\hline
\end{tabular}

\begin{tabular}{ccccc} 
Yes & 48 & 64,9 & 64,9 & 64,9 \\
No & 26 & 35,1 & 35,1 & 100,0 \\
Total & 74 & 100,0 & 100,0 & \\
\hline
\end{tabular}

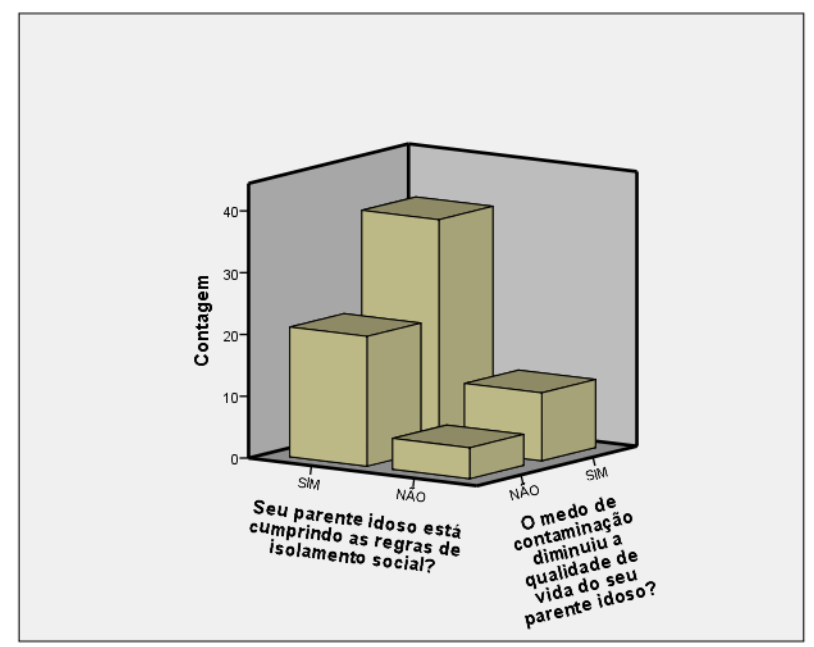

Figure 1. 3D bar chart that relates compliance with social isolation rules to fear of loss of quality of life with possible contamination. *Graph generated by SPSS v. 22.0.

When analyzing the frequency of people who reported having perceived psychological problems in their relatives, we observed that opinions are divided, and may leave a question whether relatives are really attentive to the mental health of their elderly relative (Table 3 ).

\begin{tabular}{ccccc}
\hline \multicolumn{1}{c}{ Table 3. Have you ever noticed any psychological problems in your elderly relative? } \\
\hline & Frequency & Percentage & Valid & Cumulative \\
Yes & 37 & 50,0 & 50,0 & 50,0 \\
No & 37 & 50,0 & 50,0 & 100,0 \\
Total & 74 & 100,0 & 100,0 & \\
\hline
\end{tabular}

It was observed that the number of elderlies who are not having online care during the isolation period corresponds to $90.5 \%$ of the interviewees, and only seven individuals $(9.5 \%)$ were reported who have psychological care during isolation, leading to the understanding that most of them might not have access to the Internet (Table 4).

\begin{tabular}{|c|c|c|c|c|}
\hline \multicolumn{5}{|l|}{ of isolation? } \\
\hline & Frequency & Percentage & $\begin{array}{c}\text { Valid } \\
\text { percentage }\end{array}$ & $\begin{array}{l}\text { Cumulative } \\
\text { percentage }\end{array}$ \\
\hline Yes & 7 & 9,5 & 9,5 & 9,5 \\
\hline No & 67 & 90,5 & 90,5 & 100,0 \\
\hline Total & 74 & 100,0 & 100,0 & \\
\hline
\end{tabular}

On the other hand, the appearance of different emotional behavior in this period of pandemic, marked a frequency of 42 
people (58.6\%) reported yes, and 32 people (43.2\%) reported that no, proving that there was in most cases an emotional change for the elderly in the period mentioned (Table 5).

\begin{tabular}{|c|c|c|c|c|}
\hline & Frequency & Percentage & Valid percentage & $\begin{array}{l}\text { Cumulative } \\
\text { percentage }\end{array}$ \\
\hline Yes & 42 & 56,8 & 56,8 & 56,8 \\
\hline No & 32 & 43,2 & 43,2 & 100,0 \\
\hline Total & 74 & 100,0 & 100,0 & \\
\hline
\end{tabular}

About finding that the elderly needs redoubled care during this pandemic period, most confirmed, reinforcing the idea that the elderly need greater attention and especially psychological care in this period (Table 6), according to Figure 2.

\begin{tabular}{crrrr}
\hline \multicolumn{4}{l}{ Table 6. Do you think the elderly need redoubled care in this time of isolation? } \\
\hline & Frequency & Percentage & $\begin{array}{c}\text { Valid } \\
\text { percentage }\end{array}$ & $\begin{array}{r}\text { Cumulative } \\
\text { percentage }\end{array}$ \\
Yes & 71 & 95,9 & 95,9 & 95,9 \\
No & 3 & 4,1 & 4,1 & 100,0 \\
Total & 74 & 100,0 & 100,0 & \\
\hline
\end{tabular}

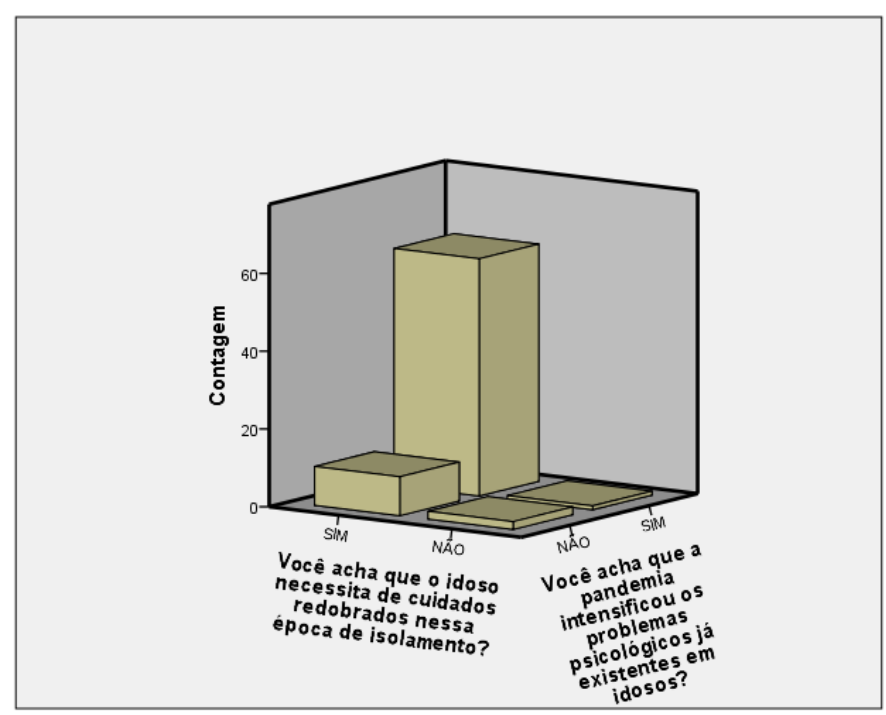

Figure 2. 3D bar graph that relates the need for redoubled care with the elderly to the increase in psychological problems already existing in the elderly, impairing their quality of life. *Graph generated by SPSS v. 22.0 .

About finding that the pandemic intensified the psychological problems already existing in the elderly, (83.8\%) answered yes, proving that the current situation of isolation requires several cares, including the performance of psychological care (Table 7).

\begin{tabular}{|c|c|c|c|c|}
\hline \multicolumn{5}{|c|}{ existing in the elderly? } \\
\hline & Frequency & Percentage & $\begin{array}{c}\text { Valid } \\
\text { percentage }\end{array}$ & $\begin{array}{l}\text { Cumulative } \\
\text { percentage }\end{array}$ \\
\hline Yes & 62 & 83,8 & 83,8 & 83,8 \\
\hline No & 12 & 16,2 & 16,2 & 100,0 \\
\hline Total & 74 & 100,0 & 100,0 & \\
\hline
\end{tabular}

When analyzing all frequencies obtained in general, it is easy to realize that the number of people who answered yes reached a high percentage rate in most of the questions presented, reinforcing our knowledge about personal and psychological care with the elderly, and the need to perceive emotional change of them, since social isolation is necessary for their own safety and physical health.

\section{Conclusions}

Based on the content exposed, it is perceived that unexpectedly imposed isolation is important especially for the elderly, but it has intensified psychological and physiological problems and affected the emotional side of these people. Similarly, it is noted that elderly people and caregivers, who also suffered impacts on mental health, did not obtain adequate psychological care, since most people in our research target are not having consultation with online psychologists to help deal with the affliction, sadness, anxiety crises and depression, which has been established, as they generally do not use social networks as a form of entertainment therefore, it is necessary to encourage the care of the old person, so that the damage caused by the pandemic does not drastically affect the quality of life of this group.

A broader look at the elderly should be turned, because they do not practice physical exercises at home, only domestic activities remain, and medical care is essential for controlling and maintaining this routine, since in addition to the fear of comorbidities arising from age, there is still the fear of contracting the virus and infecting their relatives or even not resisting respiratory syndrome, which causes such concern in themselves and in their families, who are afraid to approach as a way to protect their loved ones. Therefore, means of help should be made available to the elderly and caregivers, through the expansion of online psychological support in a simplified and accessible way, and also medical consultations as necessary to assess the well-being of the elderly population, since care needs to be doubled during this period of uncertainty, thus supplying essential needs in the lives of these individuals.

\section{Acknowledgements}

We thank our advisor Prof. Pierre Teodósio Felix for their willingness and willingness to help us, restraining our doubts when we needed to. 


\section{References}

[1] BRASIL, Ministério da Saúde, 2020. Saúde mental e atenção psicossocial na COVID-19: um guia para gestores. FIOCRUZ.

[2] BRASIL. Estatuto do idoso: lei federal $n^{\circ} 10.741$, de 01 de outubro de 2003. Brasília, DF: Secretaria Especial dos Direitos Humanos, 2004.

[3] FARO, BAHIANO, M. A., NAKANO, T. C., REIS, C., SILVA B. F. P., VITTI, L. S. COVID-19 e saúde mental: a emergência do cuidado. Estudos de Psicologia, Campinas, 37.

[4] GRINCENKOV, Fabiane Rossi. A Psicologia Hospitalar e da
Saúde no enfrentamento do coronavírus: necessidade e proposta de atuação. HU Revista, v. 46, p. 03-e. 04, 2020.

[5] SANTOS, S.S.; BRANDÃO, G. C.G.; ARAÚJO, K.M.F.A. Isolamento social: um olhar a saúde mental de idosos durante a pandemia do COVID-19. Research, Society and Development, Campina Grande, v.9, n.7, 2020.

[6] SILVA, M. L. S., VIANA, S.A.A., LIMA, P.T. Impacto na saúde mental do idoso durante o período de isolamento social em virtude da disseminação da doença COVID-19: uma revisão literária. Revista diálogos em saúde, São Paulo, v.3, n.1, 2020 